Tema: Professioner og tværprofessionalitet

\title{
Hans Jørgen Staugaard: Profession - skulle det nu være noget særligt?
}

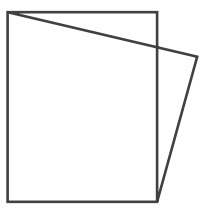

Anmeldt af Jan Thorhauge Frederiksen, lektor, Institut for Medier, Erkendelse og Formidling, Københavns Universitet
Hans Jørgen Staugaards bog påtager sig den ikke helt enkle opgave at introducere til både begrebet profession (og professionsforskningens hovedstrenge), den politiske og uddannelsesmæssige placering af professionerne i Danmark og de særlige kendetegn ved velfærdsprofessionerne. Det er en stor mundfuld at gabe over. Bogen indgår i Samfundslitteraturs serie 'Professionernes begreber' og er rettet mod velfærdprofessionelle og studerende på velfærdsprofessionsuddannelserne. Den målgruppe stiller forfatteren ovenfor en formidlingsmæssig udfordring, hvis bogen både skal knytte an til uddannelsen og til professionel praksis. Alt dette skal klares på ca. 100 sider.

Bogen er opbygget i seks dele, med tyngden i fire afsnit. Det første, 'Professioner som noget særligt', omhandler professionernes historie med udgangspunkt i de klassiske professioner. Herefter præsenteres to grundperspektiver på professionerne, konsensusperspektivet (som Parsons er repræsentant for) og konfliktperspektivet, der dækkes af Weber, Bourdieu og Abbott. Herefter udfoldes syv professionsmarkører, altså typiske træk ved professionerne. De syv er autonomi, monopol, specialisering, abstraktion, uddannelse, professionsetik og dømmekraft. Så vidt, så traditionelt; de fleste andre introduktioner til professionsforskningen, jeg kender til, betjener sig af denne opbygning. Det næste afsnit er mere utraditionelt og knytter sig meget direkte til velfærdsprofessionerne. Det handler om professionsdilemmaer og kategoriserer dem som organisatoriske og personlige dilemmaer. Her diskuteres forhold som New Public Management, professionalisering, forholdet mellem person og profession med videre. Bogen afrundes med en kort perspektivering.

Bogen lykkes i vidt omfang med den komplekse og ambitiøse opgave, den har sat sig for; det er letlæst og velskrevet og holder en uhøjtidelig tone, der ikke tager læserens interesse i diskussionerne for givet. Dette kommer også til udtryk i bogen skeptiske undertitel. Mange af professionsforskningens temaer berøres og ikke kun overfladisk. Staugaard inddrager både aktuel dansk forskning - og både praktiske empiriske eksempler, der ikke blot illustrerer, men også demonstrerer professionsforskningens relevans 
Profession - skulle det nu være noget særligt?

og refleksive potentialer. Der er dog lagt hovedvægt på de pædagogiske professioner her.

Bogen har dog også visse svagheder, som hovedsagelig er konsekvenser af dens ambitioner og begrænsede længde. Der er en klar overvægt af sociologiske teorier og begreber, og den neoweberianske professionsforskning spiller hovedrollen hele bogen igennem. Det betyder, at mere praksisnære begreber som $\mathrm{fx}$ professionsidentitet slet ikke nævnes, på trods af den store rolle det ellers har haft i dansk professionsforskning. Det er et valg, som man kan diskutere, men selvfølgelig kan alt ikke få en lige stor plads i en sådan bog. Mere problematisk er det måske, at dette fokus også fortrænger overvejelser over det særlige ved velfærdsprofessionerne fra meget af bogen. Begreber som relation og omsorg er stort set fraværende, og det får bogens blik på velfærdsarbejdets praksis til af fremstå abstrakt og objektiverende. Kun i afsnittet om professionsdilemmaer ses det velfærdsprofessionelle arbejde indefra. Og det fører mig videre til bogens anden svaghed. Bogen er helt og aldeles skrevet som monografi. En grundig, systematisk monografi med en klar fremadskridende opbygning. Det betyder, at den kun i begrænset omfang kan bruges som opslagsværk eller læses i uddrag. Flere kapitler, særligt de to om professionsmarkører og professionsdilemmaer, er ikke nemme at læse sig ind $i$ uden at have læst hele bogen. Det tror jeg begrænser dens appel til den erklærede målgruppe, og det er ærgerligt, for bogen giver både en god og grundig introduktion til sit tema, et blik på professionernes politiske og forvaltningsmæssige udfordringer, der hverken priviligerer praksis eller forvaltning og kan derfor være grundlag for reflekterede og konstruktive diskussioner af velfærdsprofessionerne i Danmark. Men altså kun, hvis man læser det hele. 